\title{
Sacred Landscape in Modern Russia's Cultural and Historical Policy Through the Eyes of St. Petersburg and the Leningrad Region Residents
}

\author{
Elena Okladnikova
}

Herzen State Pedagogical University of Russia, Department of Sociology and Religious Studies, St. Petersburg, Russia

e-mail:okladnikova-ea@yandex.ru

\section{Levon Kandaryan}

Herzen State Pedagogical University of Russia, Department of Sociology and Religious Studies, St. Petersburg, Russia

e-mail:8911969921832@mail.ru

\begin{abstract}
The purpose of this article is to publish the results of the qualitative sociological research carried out among the residents of St. Petersburg and the Leningrad Region on the possibility of using the marker monuments of their "small homeland" sacred landscape in the creation of Russia's state cultural policy. The research was done by the method of narrative interview. Based on the typological content analysis of the 179 interview transcripts, i.e. the respondents' competence level in the volume and depth of historical memory, all survey respondents were classified into three major groups: 1) experts (knowledgeable about the subject of our study), 2) improvisers (respondents who showed interest in the subject of our study but were scarcely competent in historical materials) and 3) ignoramuses (respondents who showed negative or indifferent attitudes to the research of the sacred landscape monuments). As a result, the authors have reached the following conclusions: 1) according to our respondents, the sacred landscape of St. Petersburg and the Leningrad Region has a high potential for Russia's cultural policy; 2) as our respondents' most symbolically and emotionally loaded part of their "small homeland" landscape, the socio-cultural phenomenon of the sacred landscape requires the State's delicate and careful attention; 3) in our respondents' opinion, despite its declarations and documents, the State's cultural policy is, in reality, still mainly focused on the public opinion management from the Soviet era; 4) such ideological orientation excludes the sacred landscape of our respondents' "small homeland" from the State's modern cultural policy.
\end{abstract}

Key words: sacred landscape, the cultural policy of the Russian Federation, historical memory, narrative interview, public opinion. 


\section{Introduction}

The sacred landscape is an important meaningful part of the socio-cultural field of St. Petersburg and the Leningrad Region (Okladnikova, 2014). Indigenous tribes, like the Vod, the Izhor, the Veps, the Chuds, and, later, the Slavs and the Finns, were involved in the sacred landscape formation in the Leningrad Region, whilst its formation in the territory of St. Petersburg is associated with Swedes, Russians, Germans, Finns, Italians, the French, etc. Some significant markers of this kind of landscape are the so-called cult revered sites. These sites function as signs referring us to a particular phenomenon that took place in the past. Such sites of historical landscape serve to implement the updating and transferring of socially significant information to future generations. Such signs are, for example, revered stones, springs, sacred trees and groves (many of which served as burial places, as well as departure places for the indigenous population's calendar cycle rites). Today such cult sites in the Leningrad Region form the "core" of sacred landscapes. The sacred landscape can be defined as the totality of "places" in which man, as the bearer of a historical world outlook and an in-depth historical memory, meets with the sacred. It is the historical memory that transforms a physical geographical landscape into a "living environment" which is permeated with symbolic meanings. These meanings generate the memory of the people who lived in these landscapes. For St. Petersburg, the markers of the sacred landscape are the cult buildings (cathedrals and temples erected in extracted places), legendary places where sacred trees grew, revered boulders (e.g., "The Thunder Storm" which served as a pedestal for "The Bronze Horseman" sculpture), ancient cross stones in urban necropolises, etc. Not only Christian shrines, but also sacred wellsprings, groves, commemorative crosses, revered stones, individual trees, rural cemeteries, chapels, etc. serve as such markers for the residents of the Leningrad Region.

In modern Russia's cultural policy, the sacred landscape, together with its marker monuments, is latently inherent only in the ethno-cultural section of the document that reveals the essence of this policy. This document aims at developing and supporting the ethno-cultural diversity and folklore traditions of Russia's population (Ministry of Culture of the Russian Federation, 2017). Nevertheless, according to a recent survey by the Public Opinion Foundation (POF), 81\% of Russians believe that the cultural policy development and, accordingly, the significance of the sacred landscape as a historical and cultural phenomenon is an important aspect of the social life of modern Russian society (Poll of POF, 2016). As part of North-Western Russia's historical landscape, the sacred landscape of St. Petersburg and the Leningrad Region performs a number of important functions, among them the constructive function. This kind of landscape creates cultural values, thus reuniting the material objects of artifacts, i.e. monuments, and objects of intangible cultural heritage, i.e. myths, tales, legends and skits (in Russian - "bylichki") created by the inhabitants of these landscapes over the years. Another function of the sacred landscape is the translational one. The sacred landscape transfers historically significant information from generation to generation. The third function of this landscape type is mobilization realized due to the symbolic significance of the objects forming the landscape and these objects' emotional load with this region's most important historical events. 
The functions of the cultural and cultural-historical policy are as follows: 1) protection (preservation of the sacred landscape's monuments); 2) popularization of the scientific research of the sacred landscape's monuments and propagation of their historical significance; 3) assessment and hierarchy establishment of cultural values, phenomena and facts, and 4) control over the entire process of identifying, studying, preserving and propagating Russia's historical and cultural monuments (Ministry of Culture of the Russian Federation, 2017).

At the same time, there is little research on the problem of how effectively the State's modern cultural and historical policy uses the sacred landscape markers of St. Petersburg and the Leningrad Region. The results obtained in the analysis of the materials collected by the research authors not only contribute to the national science but are also of great interest to foreign researchers due to the fact that: 1) The collection of empirical materials was carried out by qualitative sociological methods. The bases of these methods were developed for sociological data by foreign scientists of the 20th century (C. Geertz, A. Strauss, J. Corbin) and were widely used in cultural anthropology and ethnography by Russian ethnographers over 100 years ago. 3) The results of the processed field materials on the research subject realize a new stage of foreign elaboration in the theory of Political Geography and Political Sociology. This elaboration is going to be based on the materials of the latest socio-cultural studies carried out by the authors of this article on the basis of original empirical materials. 3) These results can be used abroad to study global humanitarian problems and the latest trends in international tourism.

\section{Materials and Methods}

This research aims at analyzing how effectively the Russian cultural policy's main postulates "operate". The cultural policy serves to preserve and maintain the historical memory of the modern population of the Nevsky District cultural landscapes, among them the sacred landscapes. In order to achieve the research goal, the following tasks were solved: 1) the authors created a guide including 7 blocks of questions. The first three blocks of questions referred to how respondents see the structure and form of cultural landscapes. The remaining four blocks included questions concerning the symbolic aspects of respondents' interpretation of these landscapes' sacredness. 2) During the field study, the authors collected empirical materials (i.e. 5-2-hour interviews) that were later subjected to typological processing. 3) As a result of typologically processing the interview transcripts, the authors of the research revealed some features that characterize the historical memory of the population in the Nevsky District (St. Petersburg and the southern part of the Leningrad Region). 4) The authors carried out a semantic analysis of the depth and volume of the respondents' historical memory. The results of this semantic analysis allowed for drawing conclusions on the depth and volume of St. Petersburg's and the Leningrad Region's population's historical memory in the context of the work of the State's cultural policy actors.

The authors of the research collected empirical materials by the method of narrative interview. This method substantively identifies the respondents' collective notions 
of events, phenomena and facts of sociological interest ; in other words, everything that allows the researchers to identify the latent forms of social word classification used by respondents in everyday life, as well as to find and describe perception patterns, and assessment of life situations implicit even for the respondents themselves, as well as different options (though not sufficiently studied by sociologists) people use to mark the important elements of man-made sacred landscapes. The above-mentioned potential of the narrative interview method was touched upon in A. Strauss J. Corbin's (Strauss \& Corbin, 1998) and C. Geertz' (Geertz, 1973:5) works. In addition, the method was empirically applied abroad by the scientists of the Chicago School (Park, 1925:47-62).

The processing of the research results was based on a typological methodology, which allows the authors of the research to generalize the empirical data of field studies and the documentary materials (literary sources, sociological, ethnographic and archaeological scientific materials). The typological analysis presupposes the identification of a categorical mechanism. This mechanism not only allows the authors of the research to describe the content of the respondents' statements but also reveals the symbolic load of these statements. The typological method of processing the empirical research results allowed the authors of this article to get closer to the creation of a so-called grounded theory explaining the existence of certain social phenomena, namely: a historical fact, a historical event or a process (of the formation and transmission of information through various communication channels, among them historical memory).

The research data was collected in the course of the expedition work with respondents, i.e. residents of St. Petersburg and the Leningrad Region ( $\mathrm{N}=179$ people) in 2015-2016. Our respondents were residents of the megalopolis (St. Petersburg), as well as residents of 10 settlements in the Leningrad Region, namely: the cities of Pavlovsk, Pushkin, Vsevolozhsk, Luga and Gatchina, the towns of Siverskaya, Mozhaiskoye (Kirgof, Dudegohof) and Seltso, and the villages of Monastyrka and Kotla. These people identified themselves as natives and their residence territory as their "small homeland". The survey involved respondents of three age groups: (16-29-year-old people: $\mathrm{M}=33, \mathrm{~F}=55$ ); (30-55-year-old people: $\mathrm{M}=14, \mathrm{~F}=39$ ); $(55<: \mathrm{M}=16, \mathrm{~F}=22)$. A total of 63 men and 116 women took part in the study. The selection of respondents was done by the method of "available cases" and the "snowball" sampling method.

The respondents' social representations attest how Russians perceive the efforts of the State's cultural and historical policy actors, i.e. state authorities of the Russian Federation and public institutions for the preservation and development of all culture branches, all kinds of citizens' creative activity, and personality development based on the values inherent in the Russian society. In this article, the authors have characterized these notions in general terms. These notions can serve to make judgments on the potential to attract the information about the sacred landscape monuments into the cultural and historical policy, and on the respondents' perception of the efforts by the State's cultural policy actors towards preserving these monuments and using their power as tools for forming value orientations for large population groups (the youth, working-age population, pensioners). 
As a terrestrial space and living environment of a large (self-preserving and selforganizing) group of people, the sacred landscape is part of a larger socio-cultural formation, namely the cultural landscape. The study of the sacred landscape has become the subject of several sciences, among them archaeology, ethnography, folklore, history, local history, etc. The sacred landscape space is integral and structured at the same time. It contains natural and cultural components and has been comprehended utilitarily, semantically and symbolically. Empirical studies show that sacred landscapes closely adjoin residential and economic zones and sometimes even overlap them.

For the traditional and archaic consciousness of Ancient Eurasia's population, the sacred landscape is the living environment of man-occupied (settlements, funerary valleys, resource lands) and unoccupied (mountain peaks, water spaces, taiga) spaces that are imbued with a special meaning in the consciousness of people inhabiting these spaces (Okladnikova, 2014). According to the authors of the article, the structuring (organization, regulation) of the space by allocating economic, spiritual and sacred activities conducted on the surface of the earth is a managerial, organizing and regulating process.

The main components of the sacred landscape of the Prinevsky Krai and, more broadly, the Leningrad Region include cult megalithic complexes (large boulders, large chopped stones, stone ramparts, stone heaps), old trees, sacred groves, sacred springs, ancient stone crosses, lakes, streams, etc. Sacred markers left on the surface of landscapes prove that specific boulders were revered as sacred, i.e. can be considered as objects of worship. These markers include cup-shaped depressions, broken signs (e.g., crosses, runic-like signs) and grooves, which were interpreted by local people as traces (of Virgin Mary, Paraskeva-Pyatnitsa, and other saints), as well as shape peculiarities of these stones, the nature of location in the terrain and ethnographic references to specific landmarks (legends, 'bylichki', folklore, myths), etc. Cult stones are attached to medieval settlements, portages, burial grounds (Early Iron Age, Middle Ages), graves, chapels, etc.

\section{Literature Review}

The theoretical instruments for the problems touched upon in this article were developed on the basis of the urban studies by the Chicago School of Sociology (Park, 1925:47-62). In the late 1920s, R. Park, a professor at the University of Chicago, formed a research team whose task was to study the social landscapes of the US cities. R. Park's scientific results changed humanitarians' perceptions of the structure and system of public relations in a modern city. In its essence, the theory of contemporary public spaces is an elaboration of the studies carried out by R. Park and his team. In France, one of the theoreticians representing the dynamics of public spaces was A. Lefebvre, who introduced the concept of "the right to the city" into scientific circulation. According to A. Lefebvre and his followers (A. Amin, N. Trift), the above-mentioned right presupposes access to resources. The development and creative rethinking of these spaces (both old and those newly created by different 
population groups) were studied by Ch. Tilly, G. Douglas, A. Iveson, and others. In Russia, the historian A. F. Filippov made a great contribution to the research of the history and sociology of public spaces. Public spaces include historical parts of cities. Sociologists discovered that, for example, working zones and recreation zones contribute to the formation of modern citizens' socio-cultural identity (Sagehi i Wan, 2016; Levy, 2015; Tonkiss, 2016; Wheeler i Beatley, 2014). The sacred landscape is one of public space varieties. It has a number of specific characteristics that distinguish it from the urban or rural landscape. Therefore, it is not surprising that the elaborations of Park-Lefebvre-Filippov provide the keys to understanding the structure, forms and functional characteristics of the sacred landscape.

After Park and Lefebvre, the comprehension of socio-cultural landscapes, including urban, rural and other varieties of cultural landscapes, was realized in two ways: 1) from the positions of authorities' political discourse and the population's attitude towards this discourse (M. Blok, P. Bourdieu, V. L. Kagansky); 2) by studying the sense formation processes of the poetic-aesthetic metaphor of space (A. I. Vvedenin, D. N. Zamyatin, I. I. Mitin); 3) from the standpoint of historic-cultural and archaeological approaches. The authors of this article adhered to the postulates of a symbolic approach towards studying a single variety of socio-cultural landscapes, namely, the sacred landscapes of the Nevsky district (Gary, 2004; Geertz, 1973; Nikolaeva i Kalimullina, 2016).

At the current level of humanitarian knowledge development, it is impossible to study the peculiarities of sacred landscapes and the attitude of the population inhabiting these landscapes without taking into account the socio-cultural concept of globalization (M. Castells and E. Wallerstein) and the theory of the modern society's globalization and modernization. This theory is being developed today by Russian scientists both at the micro-level (O. Berdnikova, O. Zaporozhets) and at a broader, environmental level (Goodarzi, 2016; Heidari, 2016; Okladnikova i Popov, 2016; Sagehi i Wan, 2016; Okladnikova, 2016). The environmental approach to the study of cultural landscapes includes theories of the social transformations of vast inhabited spaces. Nineteenth and early twentieth century scientists, M. Weber (Weber's theory of disenchantment of symbolic social and mental constructs) and P. A. Sorokin (the theory of socio-cultural dynamics) developed the postulates of these theories. The historical and cultural theories that describe the main functions of North-western Russia's sacred landscapes are especially important in studying the viewpoints of people inhabiting contemporary sacred landscapes. These theories were developed by both foreign (G. Varmer, S. Villerb, T. Beatley) (Wheeler i Beatley, 2014) and domestic (E. A. Okladnikova, V. G. Mizin and others) researchers (Okladnikova, 2014; Klein, 2000; Mizin, 2014, 2015, 2016; Mizin I Muhonen, 2015). This approach to the study of the historical and cultural landscape includes four directions: 1) consideration of this landscape type from the standpoint of perpetuating religious symbols (M. Eliade's theory of the secular and sacred). 2) historical and archaeological analysis of the objects and artifacts of this landscape type that were developed by the foreign representatives of the French Annales School, J. Le Goff and A. Lefebvre, as well as by American researchers in the field of cultural geography (Rowntree, Cosgrove, 1993; Tilley, 1994, Weightman, 1996). In the domestic science, 
this approach was widely used by V. G. Sushkin, A. G. Druzhinin, D. N. Zamyatin, A. I. Vvedenin (cultural and geographical aspect), I. I. Mitin (mythogeographic aspect), R. A. Kabo (socio-geographical aspect), E. A. Okladnikova (historic-cultural aspect). 3) The sacral geographical direction (D. Sopher's theory of the topography of religions). 4) The geopolitical direction (J. J. Mackinder, A. G. Dugin).

The sociological studies of the peculiarities of historical memory that preserves and transmits from generation to generation basic ideas related to the structure, form and meaningfulness (the practices of spiritualizing physical and geographical landscapes) of sacred landscapes, were carried out in the system of sociological theories related to historical memory (Ievlev, 2014; Spivak, 1993; Halemba, 2008; Nikolaeva i Kalimullina, 2016; Rüsen, 2005; Sagehi i Wan, 2016; Tollefson, 2015). In this study, the authors have used a number of theories, among them M. Halbwachs' theory on the emergence of the concept of historical memory when tradition had disappeared, the theories of historical memory developed by the French historian J. Le Goff, P. Nor, J. Rüsen, and M. Ferro, as well as the theories of historical knowledge and historical memory developed by B. Gene, R.G. Collingwood, and G. Assmann.

The authors of this article studied the problems of historical memory based on the postulates of the existing theories on historical memory (Gary, 2004; Goundar, 2016; Hylten-Cavallius, 2016; Rüsen, 2005; Sagehi i Wan, 2016; Tollefson, 2015). In sociological and methodological aspects of the research topic, a great role belongs to E. Tonkin's works devoted to studying the peculiarities of the social memory construction by different population layers.

The study, the results of which are published in this article, was aimed at researching those aspects of cultural policy, in which the population's historical memory is used at an instrumental level. To reveal the peculiarities of "historical memory's" instrumental use by the actors of the cultural policy (including the memory of the structure, form and symbolic meaning of sacred landscapes in the north-west of the Russian Federation), the authors were provided with the theories of symbolic political science, including materials on the formation of language policy (Goundar, 2016a, 2016b; Maharaj, 2015; Nagapetova et al., 2016; Rüsen, 2005; Tollefson, 2015). In this context of the research, the authors took a great interest in E. Hobsbawm's theory, "the Invention of Tradition", and its usage by authorities; M. Castell's theory, "the Power of Identity", and the political concept of symbolic power introduced by the German political scientist T. Meier.

In domestic experiences of studying the representations of the modern population based in the inhabited territories of ancient and modern sacred landscapes, the historical, historical-religious, and historical-political approaches have been applied. In foreign experiences of studying the above-mentioned problems, the historicalphilosophical, historical, as well as sociological approaches are of great importance. The latter (i.e. the sociological approach) was introduced in the first half of the twentieth century by the theorists of the Chicago School of Sociology. Within the framework of this approach, a methodology for the research of inhabited territories, including urban, rural and, later, historical-cultural environments, was developed. 
The research of the sacred landscape as a variety of cultural environment (inhabited, spiritually mastered by modern man) eventually acquired a more symbolic and humanitarian character in the domestic science than abroad.

\section{Results}

Sacred landscape markers in the representations of St. Petersburg's and the Leningrad Region's inhabitants. The category of socio-cultural space presupposes a number of concepts, which make it a universal sociological category. Sociocultural space includes physical-geographical, political, social, economic, touristic, pedagogical, and sacred spaces. The socio-cultural space, i.e. the socio-cultural landscape of a territory makes up a whole and its component parts are united by mutual values. The socio-cultural landscape and its component part, i.e. the sacred landscape, not only forms certain types of people and styles of people's behaviour, but also unites people with special feelings for a certain territory.

The sacred landscape of a city and countryside is a part of socio-cultural space. The sacred landscape markers (cult shrines, revered places, historical monuments) are important elements of the world model formation. These elements are characterized by space and structure, as well as co-existence and interaction full of deep spiritual meanings.

Listening to the respondents' stories and proceeding from the basic symbolic coordinates of the traditional worldview of North-Western Russia's autochthonous population (Slavic and Finno-Ugric tribes), the authors of the research formed a hypothetical model of the Leningrad Region's sacred landscape. The heart of this model type is the world tree (the sacred tree: birch, pine, oak). The roots of the tree go into the underworld and the crown stretches into the sky. Beside the world tree, there is a holy spring and a cult megalith. The sacred tree was often venerated in a grove, which is today associated with the concept of "shrine", i.e. the place of funeral and calendar rituals.

In the coordinates of this worldview model, the authors compiled the questions of their research guide. The guide included questions about sacred artifacts: megalithic cultic complexes (large boulders, large chopped rocks, stone ramparts, stone heaps) old revered trees, sacred groves, springs, ancient cross-stones, lakes, streams, temple complexes, cemeteries, historical monuments, as well as questions about the processes associated with them (rituals, holidays, folklore).

Religious Stones: As objects of the city's sacred landscapes, the respondents (residents of St. Petersburg) named different historical monuments, among them the city's famous necropolises (Necropolis of the St. Alexander Nevsky Lavra, the Literature Bridges, the Volkovo Cemetery), archaeological sites located both in the city and beyond its boundaries. As archaeological monuments of the city, our respondents named the Nien Fortress (Nyenskans). When it came to the legends associated with the monuments, our respondents reproduced obscure stories about drowned 
women (perhaps, referring to Lisa's story from P.I. Tchaikovsky's opera, "The Queen of Spades"). As cult boulders, the respondent townspeople named "The Thunder Stone" and the granite monolith of "The Alexandrian Pillar". The views of the Leningrad Region's residents were more diverse. As markers of the sacred landscape, they named some of the major revered boulders, such as "The Sedlovaty Kamen" (village of Luiseño, Kingiseppsky District, the Leningrad Region), "The BesovKamen" (town of Seltso, Volosovsky District, the Leningrad Region), "The Stone Head" (Peterhof, the Sergeevka Park), "The Horse Stone" (Konevets Island), the stone of "ParaskevaPyatnitsa" near the village of Iljussa, as well as the petroglyphs of Lake Onega and the White Sea, and "The Veles Stone" on "The Noise Mountain". Our respondents from the Leningrad Region told us that some major boulders have been revered as objects of worship since ancient times. Such markers of the sacred landscape are characterized by "somberness", "somber" features.

"We all know well this huge stone in the forest, "The Besov Kamen" (town of Seltso, Volosousky District, the Leningrad Region). Suddenly and unexpectedly for ourselves, we were not able to find it. We walked and walked around our familiar places... walked all around... but we couldn't find the stone." (F, 34 years old) (The author's archive, 2015).

"... This "Sedlovaty Kamen" near the village of Luiseño (Kingiseppsky District, the Leningrad Region) is notorious among the local population. Some local men showed it to me. They told me that when they were drunk they saw some bad things at this stone. They told me not to come here... and not to show this stone to anyone. - What exactly did those men see bere? - They did not tell me. All they said was that they were drunk and they saw something bad. They said I had better not go to the stone... That is it..." (F, 70 years old) (The author's archive, 2015).

Sacred Springs: The respondent townspeople did not name a single sacred spring, an object of worship inside the city, while the residents of the Leningrad Region mentioned the Spring of St. Panteleimon in the village of Kalozhitsy, the Sacred Spring near the village of Iljussa, and the Sacred Spring in the city of Luga (the legend has it that the spring arose in the place where the body of an innocent murdered girl was brought).

Sacred Groves and Trees: As revered trees, the oak tree on the Krestovsky Island was named by the respondent townspeople. Legend has it that it is the very tree, under which Peter the Great rested. They also mentioned the grove on the Old Peterhof Road, where too, they believed, Peter the Great had a rest on his way to Peterhof. Another sacred oak grove was on the Riga River. This is where Izhor women gathered for Ivan Kupala Day, they danced, sang and sacrificed a white cock. According to the legend, Peter the Great liked to stop and rest in the shade of this oak grove (Spivak, 1993). The cult of the sacred tree, in particular, pine and oak trees goes back to the 18th century Finnish population of Ingermanland. Local inhabitants organized archaic rituals around this sacred tree (Spivak, 1993). The respondents of the survey also mentioned the pine tree with a forked trunk. Legend has it that by 
Peter the Great's order the foundation stone for the Kunstkammer was laid in the place where this pine tree grew. Among the respondents from the Leningrad Region, there were a few amateur historians. In their interviews, they mentioned the grove in place of the old cemetery on the way to Ust-Luga, on the turn to the village of Kattila. According to the legend, the grave of the "arbui"-priest (soothsayer) might be in this very grove (The author's archive, 2015). The term "arbui" was introduced in 1534 and goes back to the Novgorod chronicles. According to the data of the etymological dictionary, the word "arbui" comes from the Finnish word "arpoja", which means soothsayer, predictor (Vasmer's Etymological Dictionary of Russian, 2016).

Below is a typical answer the majority of our respondent townspeople gave to the question on sacred groves and trees:

"We do not have any groves as such. There are places with ruins of ancient churches. They are sacred for the Finn. Local people do not go there at all... There was a large beautiful brick church in the place of the House of Culture. However, the Soviet authorities demolished it. Now there are only photographs left." (F, 20 years old) (The author's archive, 2015).

Sacred groves are often associated with ancient sacred trees. For example, a sacred oak is located in the forest near the village of Cortino (Kingiseppsky District, the Leningrad Region). If you want to see this tree, you have to go down the forest slope into the thicket. The size of the tree is impressive. The age of the oak tree probably exceeds two hundred years. The local people told us that on the outskirts of the forest there is one more "Sacred Grove" in the fields behind the village of Dobryanitsa (the Leningrad Region). During the conversations with local residents, the authors discovered that they do not consider the grove a sacred place; it is just that the local youth celebrated the Ivan Kupala Day at the grove. Back in the 1970s, the youth of the village used to burn fires and organize night festivities there. According to the residents of Seltso, there is another grove and "a pagan temple" not far from the town (The author's archive, 2015). Another sacred tree is the birch tree that grew by the old chapel in the village of Iljussa. Even today, Orthodox believers worship the birch tree that grew in the place of the previous one that was felled during the years of fighting religious propaganda. Many of our respondents' stories about the sacred groves of the Leningrad Region were quite vague. Instead of sacred groves, our respondents living in the Leningrad Region more often named sacred springs they allegedly knew in the territory of Pavlovsk. However, they did not specify exact locations. The respondents often failed to understand our questions about the objects of the sacred landscape in the Leningrad Region. They did not know what "sacred groves" are. They, of course, talked about pagan temples during the interviews. However, their reports were mostly inaccurate and largely descriptive. The answers to our question about sacred groves and the concretization of the answers aroused in the minds of our respondents a great number of unsystematic associations and images: from arguments about gardens and parks of St. Petersburg's suburb palaces to the Lindulov grove, and obscure references to the name origin of the town of Pupyshevo. 
Table 1.

The Level of Respondents' Representations of the Sacred Landscape Monuments of their "Small Homeland"

\begin{tabular}{|l|c|c|}
\hline $\begin{array}{l}\text { Level of competence in the region's } \\
\text { sacred landscape monuments }\end{array}$ & \multicolumn{2}{|c|}{ Respondents } \\
\hline & Male & Female \\
\hline Low & $51 \%$ & $50 \%$ \\
\hline Medium & $29 \%$ & $21 \%$ \\
\hline High & $20 \%$ & $29 \%$ \\
\hline Total & $100 \%$ & $100 \%$ \\
\hline
\end{tabular}

The respondents were more aware of cult stones. As objects of the archaic (prePetrine) sacred landscape in St. Petersburg and the Leningrad Region, sacred springs and sacred groves were the least recognized by our respondents' consciousness. In general, a half of respondents, both men (51\%) and women (50\%) of all ages showed a low level of competence in the sacred landscape monuments of their "small homeland". $29 \%$ of men and $21 \%$ of women showed an average level of awareness of the topic. $20 \%$ men and $29 \%$ of women showed a high level of awareness (Table 1 ). In the course of our research in 2015-2016, the authors of the research discovered a great gap in the historical consciousness of the respondents living in the city and the oblast - a gap between what surrounds them (the natural landscape) and what they actually "see" (the urban historical landscapes, historical monuments, socio-cultural landscape), i.e. between the meanings they generate in relation to our research objects: historical and socio-cultural landscapes.

\section{Discussion}

The sacred landscape in the cultural-historical policy: perspectives of use. In what way do the respondents see the social importance of sacred landscape markers (both urban and rural) in the Leningrad Region? How do they perceive the possibility of using the sacred landscape for the purposes of the State's cultural policy?

During the expedition in 2015-2016, the authors discovered two vivid examples of creating/recreating material values that today become valuable artifacts for the local population. These artifacts function as material accumulators of the sacred landscape. For example, the complex (the Sacred Spring, the Sacred tree and the Sacred Stone) in place of the old chapel near the village of Iljussa and "The Besov Kamen" (town of Seltso).

"... This stone ("The BesovKamen") is located in the forest. I go there with the kids every spring... We have a picnic by the stone; the kids stay up all night... I do not sleep either.. My pupils told me they went to the stone on their own in the summer. Unexpectedly for themselves, they could not find the stone... They walked and walked around their familiar places... walked all around... but they could not find the stone. It turns out that the stone does not show up to everybody. Not everybody can see it... Now, many years later, a lot of people 
gather around the stone in summer. They leave so much rubbish all around... Before the perestroika, when I was young my husband and I came bere to live and work. Back then, the stone was hard to find. Few people knew the way to the stone..." (F, 43 years old) (The author's archive, 2015).

We found out that a complex of intangible cultural heritage, namely, folk legends, is associated with "The Besov Kamen".

"... There is a legend associated with this stone. Legend has it that there was once a church in this place. Because of people's bad behaviour, the church turned into a stone..." (P-T, F, 15 years old) (The author's archive, 2015).

"... There is a tale associated with "The Besov Kamen". It does not show up to anyone. Only open, honest people can see it - or those who are in need of help..." (F, 16 years old) (The author's archive, 2015).

Judging by the statements of our respondents living in the Leningrad Region, a lot of sacred objects, namely, cult boulders, sacred trees and sacred groves, not only fit organically into the system of local people's notions of their "small homeland's" sacred landscape markers, but also practically implement the function of this type of cultural landscape.

"... Well, now we go to "The Besov Kamen" on excursions, we take kids to the stone. Many children go there from different regions, different schools... People say the stone will not allow anybody with evil intentions to approach it..." (F, 43 years old) (The author's archive, 2015).

In our respondents' narratives, their representations of sacred springs are associated with female images (ranging from saints and martyrs to drowned women). Another system of association makes a connection between sacred springs and legends about miraculous healings and purifying rituals. A number of sacred springs were revered by autochthons of the Prinevsky District. They were later incorporated by the Christian religion and included in church and monastery architectural complexes.

The mobilizing function of the sacred landscape (both in St. Petersburg and the Leningrad Region) is reflected in our respondents'emotions, historical experiences and associations in connection with cult stones, sacred springs, sacred groves and trees. Some of the respondents told us legends about Veles, the god of cattle when they spoke about "The BesovKamen" and "The Horse Stone". The respondent townspeople spoke about Perun when they referred to "The Thunder Storm". Today, cult stones, in particular, stones with cup-shaped depressions near the village of Olkhovka (Lake Sukhodolskoye) have become centres of "new" sacred landscapes. Thus, the "cup" complex near the village of Olkhovka, "The BesovKamen" are considered places of contemporary neo-pagan and neo-esoteric practices. The numerous visitors ("informals", "reenactors", "esotericists", "ufologists", etc.) leave money (coins), cheap jewellery, candles and bread at by the "traced stones", "cups". Similarly, new markers were formed by the "informals" in the places of the ancient landscapes that 
had already been forgotten by the local population. These formation processes are described in the modern scientific literature (Broz, 2011: 275, 276; Halemba, 2008; Klein, 2000; Plets et al., 2013).

\section{Conclusion}

In summary, the results of this research contribute to modern world science due to the fact that: 1 . For the first time, original field data (collected by the method of qualitative sociological research, and scientifically structured and processed by the typological method) has been published; 2 . The originality of the materials lies in the fact that this sociological topic was not previously researched in the Nevsky District (St. Petersburg and the Leningrad Region); 3. The results of our observations are not known to the world of science. Nevertheless, they cannot but be of interest to the world scientific community as the problems of traditional culture and other related topics of historical memory, preservation of cultural heritage and sacred landscapes is an important trend of modern historic-cultural and socio-cultural research in global human sciences.

Most of the respondents, both men and women, were "Ignorant". They showed no interest in the history of their region and the tangible cultural heritage of their "small homeland". The number of men and women we classify as "Improvisers" is approximately identical. These are the people who used different associations and tried to recall anything about the monuments of their "small homeland's" tangible cultural heritage. The third group of respondents are "Experts" of the region's cultural heritage monuments that form the sacred landscape of their "small homeland". The overwhelming majority of the "Experts" were women (twice exceeding the number of our male respondents) who showed competence in historical information (ranging from awareness of the sacred stone locations to information about the legends, tales, memorates and other folklore traditions related to this cultural heritage). Our respondents named cult stones as the most significant markers of the sacred landscape and sacred springs as the least significant ones. Our respondents did not link the monuments of the sacred landscape with the State's cultural policy. They did not speak of the State's efforts towards preserving the above-mentioned cultural objects and propagating their significance. Our respondents believed that the research of the above-mentioned objects is the job of local ethnographers. According to our respondents, like in the Soviet era, the State continues to either smash the objects of cultural heritage as ideologically alien ones or simply ignore them. Just as it was in the Soviet era, the authorities evade responsibility for the preservation of this part of cultural and historical heritage, which is either used for farming or given to the church for the restoration, renovation and use of historical, aesthetic, architectural and museum potential of temples and churches, or to selforganizing religious communities and sects (for example, esotericists). That is why such important markers of the sacred landscape (cult stones, sacred springs, sacred groves and trees) turn out to be in the sphere of mobilization practices of "esoteric", "neo-pagan" and "ufologist" communities, etc. The actors of the State's cultural policy are, however, not involved in these practices. The only experience of using 
a cult stone (town of Seltso) as a system-forming marker of the "small homeland's" sacred (historical) landscape was implemented solely on a voluntary basis by one of our respondents, the director of a local secondary school. Our respondents did not speak of any attempt on the part of state authorities to use the very phenomenon of "sacred landscape" in the nationwide integration of the population of St. Petersburg and the Leningrad Region.

The practical significance of this research lies in the fact that the conclusions of the study can serve as recommendations to the actors of the cultural policy of the Russian Federation. The research has shown that the sacred landscape of the "small homeland", both urban and rural, has a high motivational and integrative potential to be used in the cultural policy of the State. The positive attitude of our respondent "Experts" and "Improvisers" is proof of the effectiveness of attracting emotionally and symbolically loaded monuments that mark this landscape type. The historicalcultural phenomenon itself, due to its specifics "closed", i.e. "concealed" from "profanes", requires an exceptionally delicate and careful attitude if used as instruments of the State's cultural policy. The data of our research can be used in pedagogical practice, for example, as materials for supplementary education programs and for expanding the materials of standard academic courses in general humanities. In addition, the practical output of the study can be used by actors of the tourism industry to expand the opportunities of the tourist business in the north-west of the Russian Federation. This can be done through actively introducing into various tour programs the markers of archaic sacred landscapes, which currently evoke only scientific (archaeological) interest.

The research turned out to be very productive. In addition, it paved the way for new research perspectives, namely: 1) perspective for expanding the geography of empirical research and propagating the practice of narrative interviews in the northern regions of the Nevsky District; 2) deeper research of the problems of studying respondents' on a broader range of issues related both to the cultural and symbolic policy of the State.

\section{Acknowledgements}

We express our special gratitude to the group of expert respondents: the historian V.G. Mizin, head of "The Silver Ring of Russia" NGO, and N.F. Babkina, founder of the ethnographic museum in the village of Monastyrka. Without the creative and benevolent participation of these people, our research would not have succeeded as a scientific event. 


\section{References}

1. Abbassi, Z. (2017). Cultural Memory / Collective Memory as a way of Resistance to Traumatic memory. International journal of humanities and cultural studies, 3 (1): 36-47.

2. Broz, L. (2011). Spirits, Genes and Walt Disney's Deer: Creativity in Identity and Archaeology Disputes (Altai, Siberia), in: The archaeological encounter: anthropological perspective. St. Andrews.

3. Gary, R. V. (2004). Menhirs, dolmen and circles of stone: the folklore and magic of sacred stone. New York: Algora Publishing.

4. Geertz, C. (1973). Thick Description: Toward an Interpretative Theory of Culture, in: The Interpretation of Cultures. New York: BasicBooks.

5. Goodarzi, M. (2016). Globalization and City Diplomacy: The Formation of Global Citizen (Possibility or Impossibility). International journal of humanities and cultural studies, 3 (1): 474-487.

6. Goundar, P. A. (2016). Socio-linguistic Outline of Language Policy and Planning (LPP): Reference to LPP in Fiji. International journal of humanities and cultural studies, 3 (2): 688-699.

7. Goundar, P. (2016). Keep your culture. The challenge for South Indians in Fiji, The Fiji Times. http://www.fijitimes.com/story.aspx?id=338105. (Accessed 9 May 2017)

8. Halemba, A. (2008). What does it feel like when your religion moves under your feet? Religion, Earthquakes and National Unity in the Republic of Altai, Russian Federation. Zeitschrift für Ethnologie, Bd. 133, H. 2, P. 283-287, P. 294-297.

9. Heidari, A. (2016). The Impact of Globalization on Futurism and Major Drivers: A Survey. International journal of humanities and cultural studies, 3 (2): 798809.

10. Hylten-Cavallius, S. (2016). Nostalgia for Futures Past: The Politics of Generational Memory. http://www.vanderbilt.edu/rpwcenter/pdfs/HYLTN2.PDF. (Accessed 14 May 2017)

11. Ievlev, N. V. (2014a). Ivans Remembering Ancestors. Architect. 21st century, 1 (50): $72-74$.

12. Ievlev, N. V. (2014b). Spiritual Dominants as the Most Important Factor in the Socio-economic Development of the Region. Collection of the materials of the International Scientific-Practical Conference, Kingisepp, April 4, $2014 / 9^{\text {th }}$ Yamburg Readings edited by Professor V.N. Skvortsov, Ultra-Print, St. Petersburg, p. 333.

13. Klein, K. L. (2000). On the Emergence of Memory in Historical Discourse. Representations, 69: 127-150.

14. Levy, J. M. (2015). Contemporary urban planning. London: Routledge.

15. Maharaj, M. (2015). English under the microscope. http://www.fijitimes.com/ story.aspx?id=313561. (Accessed 14 May 2017)

16. Ministry of Culture of the Russian Federation. (2017). Fundamentals of the State Cultural Policy. http://mkrf.ru/upload/mkrf/mkdocs2016/OSNOVI-PRINT.NEW. indd.pdf. (Accessed 9 May 2017)

17. Mizin, V. G. I and Muhonen, T. (2015). New field researches and some historical references on stone cairns of Ingermanland. Muinastutkija, 4: 39-53. 
18. Mizin, V. G. (2014). Footprint Stones: Summarizing a Century of Petrosomatoglyphic Study. Time and Mind, 7: 297-308.

19. Mizin, V. G. (2015). Stone Labyrinths of Finnmark and Arctic Russia. Caerdroia, 44: 23-39.

20. Mizin, V. G. (2016). Babylons: toponyms and symbolism of stone labyrinth in Arctic Russia. Time and Mind, 9: 143-158.

21. Nagapetova, A. G.; Novikova, O. S.; Pokhilko, A. D.; Shmatko, A. A.; Vetrov, Y. P. (2016). Social-Historical Transformations in Russia. International journal of bumanities and cultural studies, 3: 1439-1444.

22. Nikolaeva, E. and Kalimullina, Y. (2016). Image of the State as a Conceptual Fractal. International journal of humanities and cultural studies, 3: 35-41.

23. Okladnikova, E. (2016). Paleoglobalisation: the symbolism of prosperity and decline in rock art of ancient Eurasia. International Journal of Humanities and Cultural Studies. http://www.ijhcs.com/index.php/ijhcs. (Accessed 14 May 2017)

24. Okladnikova, E. A. and Popov, V. A. (2016). Marova A.Globalization and the dynamics of value markers of the "generation's images" in the narratives of inhabitants of St.-Petersburg and Leningrad region. International Journal of Humanities and Cultural Studies. http://www.ijhcs.com/index.php/ijhcs. (Accessed 14 May 2017)

25. Okladnikova, E. A. (2014). Sacred Landscape: Theory and Empirical Research. Moscow: Direct-Media.

26. Park, R. E.; Burgess, E. W. and McKenzie, R. D. (1925). The city. Chicago: University of Chicago Press: 47-62.

27. Plets, G.; Konstantinov, N.; Soenov, V.; Robinsson, E. (2013). Repatriation. Doxa, and Contested Heritages: The Return of the Altai Princess in an International. Anthropology and Archaeology of Eurasia, 52 (2): 74-84, 88-93.

28. Poll of POF. (2016). Opinions of Russians on Cultural Policy. http://fom.ru/ Kultura-i-dosug/12148. (Accessed 9 May 2017)

29. Rüsen, J. (2005). History: narration-interpretation-orientation. London: Berghahn Books.

30. Rüsen, J. (2006). Historical consciousness: Narrative Structure, Moral function, and Ontogenetic Development, in: Theorizing historical consciousness. Toronto: University of Toronto Press.

31. Sagehi, G. and Wan, Y. (2016). Role of Public Space on Social Identity. International journal of humanities and cultural studies, 3 (2): 1525-1531.

32. Spivak, D. L. (1993). The Finnish Substrate in Metaphysics of Petersburg, u: Petersburg Readings on the History and Theory of Culture. Metaphysics of Petersburg. Saint Petersburg: Eidlos.

33. Strauss, A. and Corbin, J. (1998). Basics of Qualitative Research: Techniques and Procedures for Developing Grounded Theory (2nd ed.). Thousand Oaks: Sage Publications.

34. The author's archive. (2015). St. Petersburg.

35. Tollefson, J. W. (2015). Historical-Structural Analysis 13. Research Methods in Language Policy and Planning: A Practical Guide.

36. Tonkiss, F. (2016). Space, the city and social theory: Social relations and urban forms. Cambrige: Polity Press. 
37. Vasmer's Etymological Dictionary of Russian, 1964-1973. (2016). http://www. slovorod.ru/etym-vasmer/ pdf/vasmer-etymologic-dict1.pdf. (Accessed 9 May 2017)

38. Wheeler, S. M. and Beatley, T. (2014). Sustainable Urban Development Reader. London: Routledge. 
Prethodno priopćenje

Elena okladnikova

Herzen Državni pedagoški fakultet Sveučilišta u Rusiji, Odsjek sociologije i religijskih znanosti, Sankt Peterburg, Rusija

e-mail: okladnikova-ea@yandex.ru

Levon Kandaryan

Herzen Državni pedagoški fakultet Sveučilišta u Rusiji, Odsjek sociologije i religijskih znanosti, Sankt

Peterburg, Rusija

e-mail:8911969921832@mail.ru

\section{Pogled stanovnika Sankt Peterburga i Lenjingradske oblasti na sakralni krajolik i njegovo mjesto u kulturnoj i povijesnoj politici moderne Rusije}

\section{Sažetak}

Svrha je ovog članka objavljivanje rezultata kvalitativnih socioloških istraživanja provedenih među stanovnicima Sankt Peterburga i Lenjingradske oblasti o mogućnosti korištenja markantnih spomenika zavičajnoga sakralnog krajolika u kreiranju državne kulturne politike. Istraživanje je provedeno metodom pripovjednog intervjua. Na temelju tipološke analize sadržaja 179 transkripata intervjua, tj. razine kompetencije ispitanika u vezi s opsegom i dubinom njihove povijesne memorije, svi ispitanici razvrstani su u tri glavne skupine: 1) eksperti (dobri poznavatelji predmeta istraživanja), 2) improvizatori (ispitanici koji su pokazali zanimanje za predmet studije, ali im je kompetencija nedostatna kada su u pitanju povijesni materijali) i 3) ignoranti (ispitanici koji su pokazali negativne ili indiferentne stavove u vezi istraživanja spomenika sakralnog krajolika). Autori istraživanja došli su do sljedećih zaključaka: 1) prema mišljenju ispitanika, sakralni krajolik Sankt Peterburga i Lenjingradske oblasti ima veliki potencijal za državnu kulturnu politiku; 2) zbog snažnog simboličkog i emotivnog naboja što ga u ispitanicima stvara, sociokulturni fenomen sakralnog krajolika zahtijeva delikatan i pažljiv pristup države; 3) prema ispitanicima, unatoč deklarativnoj podršci i dokumentima, kulturna se politika države zapravo još uvijek oslanja na model upravljanja javnim mnijenjem iz vremena Sovjetskog Saveza; 4) takva ideološka orijentacija isključuje sakralni zavičajni krajolik ispitanika iz instrumenata moderne državne kulturne politike.

Ključne riječi: sakralni krajolik, kulturna politika Ruske Federacije, povijesna memorija, narativni intervju, javno mnijenje. 